\title{
Histocompatibility antigens in patients with alcoholic liver disease in Scotland and northeastern England: failure to show an association
}

\author{
P R MILlS, R N M MacSWEEN, H M DICK, AND W S HISLOP \\ From the Departments of Medicine and Clinical Immunology, Royal Infirmary, Glasgow, University \\ Department of Pathology, Western Infirmary, Glasgow, and University Department of Medicine, Ninewells \\ Hospital, Dundee, Scotland
}

SUMmARY A study of HLA-A and B antigens in 248 patients with biopsy diagnosed alcoholic liver disease was conducted to examine for a genetic predisposition to alcohol related liver injury. No statistically significant differences were established for 8 HLA-A and 16 HLA-B antigens between normal healthy controls $(n=342)$ and patients with alcoholic fatty liver $(n=86)$, alcoholic hepatitis $(n=63)$, active alcoholic cirrhosis $(n=64)$ and inactive alcoholic cirrhosis $(n=35)$. It is concluded that no HLA-A or B locus genetic susceptibility to alcoholic related injury could be shown.

Epidemiological surveys have indicated that the risk of developing alcoholic cirrhosis is related both to the amount and duration of alcohol abuse.' On the basis of numerous histological surveys of liver disease among chronic alcoholics, however, it is estimated that only $30 \%$ of heavy drinkers will develop alcoholic hepatitis and $10-15 \%$ cirrhosis. ${ }^{2+}$ Clearly, other constitutional or environmental factors must, therefore, play a role in determining individual susceptibility to alcoholic liver disease. Genetic influences have been explored by studying major histocompatibility antigens in patients with established alcoholic liver disease. Several small studies were reported in the late 1970s showing isolated and conflicting associations of HLA-A and B antigens with alcoholic liver disease. An extensive review of the literature in 1982 concluded that no single HLA antigen was associated with a predisposition to alcoholic liver disease and that most of the studies reported on rather small numbers of patients with variable criteria for selection. ${ }^{5}$ Simultaneously, in 1982 a large single centre study of 170 British chronic alcoholics with and without liver disease failed to show any relationship between HLA antigens and susceptibility to alcoholic cirrhosis. ${ }^{6}$

Address for correspondence: Professor R N M MacSween, University Department of Pathology, Western Infirmary, Glasgow G11 6NT.

Received for publication 31 July 1987.
The controversy was reawakened in 1986 by the publication of two studies; one from France which showed an increased prevalence of HLA-B15 and reduced prevalence of $\mathrm{B} 13$ in patients with alcoholic cirrhosis $^{7}$ and one from the USA which showed an increased prevalence of $B 8$ in whites with moderately severe alcoholic hepatitis. ${ }^{8}$

Therefore, we have been stimulated to report our own findings. As part of an extensive epidemiological study of 510 patients with histologically proven alcoholic liver disease in Scotland and northern England," class I histocompatibility antigens were typed in a randomly selected cohort of 327 patients.

\section{Methods}

PATIENTS

Patients were accessed at seven centres in Scotland and one in Newcastle as part of a collaborative study of the Caledonian Society of Gastroenterology. ${ }^{9}$ All patients were British, caucasian, had a history of regular alcohol consumption in excess of $60 \mathrm{~g}$ daily and histological evidence of alcoholic liver disease. Patients were classified histologically as showing fatty liver, alcoholic hepatitis, active alcoholic cirrhosis (together with alcoholic hepatitis) or inactive alcoholic cirrhosis.

All samples for HLA typing were transferred to 
Table HLA-A and HLA-B antigens in patients with alcoholic liver disease and controls

\begin{tabular}{|c|c|c|c|c|c|c|c|c|c|c|}
\hline & $\begin{array}{l}\text { Controls } \\
\text { Total } 342 \\
\text { (n) }\end{array}$ & $\begin{array}{l}\text { Freq } \\
(\%)\end{array}$ & $\begin{array}{l}\text { Alcoholic } \\
\text { fatty liver } \\
\text { Total } 86 \\
\text { (n) }\end{array}$ & $\begin{array}{l}\text { Freq } \\
(\%)\end{array}$ & $\begin{array}{l}\text { Alcoholic } \\
\text { hepatitis } \\
\text { Total } 63 \\
(n)\end{array}$ & $\begin{array}{l}\text { Freq } \\
(\%)\end{array}$ & $\begin{array}{l}\text { Active al } \\
\text { cirrhosis } \\
\text { Total } 64 \\
(n)\end{array}$ & $\begin{array}{l}\text { Freq } \\
(\%)\end{array}$ & $\begin{array}{l}\text { Inactive a } \\
\text { cirrhosis } \\
\text { Total } 35 \\
(n)\end{array}$ & $\begin{array}{l}\text { Freq } \\
(\%)\end{array}$ \\
\hline A1 & 138 & $40 \cdot 3$ & 35 & $40 \cdot 7$ & 26 & $41 \cdot 3$ & 22 & 34.4 & 16 & $45 \cdot 7$ \\
\hline A2 & 163 & $47 \cdot 6$ & 38 & $44 \cdot 2$ & 35 & $55 \cdot 5$ & 35 & $54 \cdot 7$ & 16 & $45 \cdot 7$ \\
\hline A3 & 78 & $22 \cdot 8$ & 22 & $25 \cdot 6$ & 15 & $23 \cdot 8$ & 19 & 29.7 & 3 & $8 \cdot 6$ \\
\hline A9 & 60 & $17 \cdot 5$ & 15 & $17 \cdot 4$ & 10 & $15 \cdot 9$ & 11 & $17 \cdot 2$ & 3 & $8 \cdot 6$ \\
\hline A10 & 21 & $6 \cdot 1$ & 7 & $8 \cdot 1$ & 0 & 0 & 5 & $7 \cdot 8$ & 3 & $8 \cdot 6$ \\
\hline A11 & 26 & $7 \cdot 6$ & 10 & $11 \cdot 6$ & 8 & $12 \cdot 7$ & 5 & $7 \cdot 8$ & 3 & $8 \cdot 6$ \\
\hline A28 & 31 & $9 \cdot 0$ & 6 & 6.9 & 2 & $3 \cdot 2$ & 3 & $4 \cdot 7$ & 3 & $8 \cdot 6$ \\
\hline A29 & 16 & $4 \cdot 6$ & 3 & $3 \cdot 5$ & 2 & $3 \cdot 2$ & 6 & $9 \cdot 4$ & 3 & 8.6 \\
\hline Blank & 155 & $44 \cdot 2$ & 35 & $40 \cdot 7$ & 28 & $44 \cdot 4$ & 22 & $34 \cdot 4$ & 20 & $57 \cdot 1$ \\
\hline B5 & 21 & $6 \cdot 1$ & 5 & $5 \cdot 8$ & 7 & $11 \cdot 1$ & 3 & $4 \cdot 7$ & 2 & $5 \cdot ?$ \\
\hline B7 & 93 & $27 \cdot 2$ & 23 & $26 \cdot 7$ & 18 & $28 \cdot 6$ & 18 & $26 \cdot 5$ & 14 & $40 \cdot 0$ \\
\hline B8 & 105 & $30 \cdot 7$ & 23 & $26 \cdot 7$ & 23 & $36 \cdot 5$ & 19 & $29 \cdot 7$ & 10 & $28 \cdot 6$ \\
\hline B12 & 114 & $33 \cdot 3$ & 30 & 34.9 & 26 & $41 \cdot 3$ & 16 & $25 \cdot 0$ & 11 & 31.4 \\
\hline B13 & 15 & $4 \cdot 3$ & 2 & $2 \cdot 3$ & 2 & $3 \cdot 2$ & 2 & $3 \cdot 1$ & 3 & $8 \cdot 6$ \\
\hline B14 & 29 & $8 \cdot 5$ & 7 & $8 \cdot 1$ & 4 & $6 \cdot 3$ & 8 & $12 \cdot 5$ & 2 & $5 \cdot 7$ \\
\hline B15 & 29 & $8 \cdot 5$ & 6 & $6 \cdot 9$ & 8 & $12 \cdot 7$ & 3 & $4 \cdot 7$ & 1 & $2 \cdot 8$ \\
\hline B16 & 10 & $2 \cdot 9$ & 4 & $4 \cdot 6$ & 0 & 0 & 3 & $4 \cdot 7$ & 1 & $2 \cdot 8$ \\
\hline B17 & 26 & $7 \cdot 6$ & 11 & $12 \cdot 8$ & 4 & $6 \cdot 3$ & 2 & $3 \cdot 1$ & 2 & $5 \cdot 7$ \\
\hline B18 & 19 & $5 \cdot 5$ & 6 & 6.9 & 1 & 1.6 & 4 & $6 \cdot 2$ & 0 & 0 \\
\hline Bw21 & 7 & $2 \cdot 0$ & 1 & $1 \cdot 2$ & 2 & $3 \cdot 2$ & 4 & $6 \cdot 2$ & 0 & 0 \\
\hline $\mathrm{Bw} 22$ & 13 & $3 \cdot 8$ & 2 & $2 \cdot 3$ & 1 & 1.6 & 3 & $4 \cdot 7$ & 2 & $5 \cdot 7$ \\
\hline B27 & 27 & 7.9 & 8 & $9 \cdot 3$ & 5 & 7.9 & 6 & $9 \cdot 4$ & 6 & $17 \cdot 1$ \\
\hline Bw35 & 29 & $8 \cdot 5$ & 7 & $8 \cdot 1$ & 3 & $4 \cdot 8$ & 9 & $14 \cdot 1$ & 2 & $5 \cdot 7$ \\
\hline B37 & ${ }^{*} \mathrm{NT}$ & & 6 & 6.9 & 1 & 1.6 & 4 & $6 \cdot 2$ & 0 & 0 \\
\hline B40 & 30 & $8 \cdot 8$ & 8 & $9 \cdot 3$ & 6 & $9 \cdot 5$ & 12 & $18 \cdot 7$ & 6 & $17 \cdot 1$ \\
\hline Blank & 117 & $34 \cdot 2$ & 23 & $26 \cdot 7$ & 15 & $23 \cdot 8$ & 12 & $18 \cdot 7$ & 8 & 22.9 \\
\hline
\end{tabular}

${ }^{*} \mathrm{NT}=$ not tested.

the Tissue Typing Laboratory at Glasgow Royal Infirmary. Twenty millilitres of blood were collected in heparinised tissue culture medium and lymphocytes separated over Ficoll-Hypaque using a differential centrifugation technique." Separated lymphocytes from patients were then stored in liquid nitrogen to enable the same panel of HLA typing sera to be used throughout the entire study. Histocompatibility locus antigens of $\mathrm{A}$ and $\mathrm{B}$ loci were then determined by lymphocyte microcytotoxicity test" using a panel of over 100 sera which were standardised against an International Histocompatibility Workshop cell panel. Histocompatibility locus antigen control data were derived from a population of 342 healthy unrelated individuals from the Glasgow area. ${ }^{12}$ When only a single antigen was found in any locus a blank was recorded rather than regarding the patients as being homozygous. For some antigens, it was not possible to provide sufficient typing serum and these were omitted from the analysis.

Statistical differences between patients and controls were examined using the $\chi^{2}$ test or Fisher's exact test where appropriate. Type I errors were avoided by multiplying the $p$ value obtained by the number of antigens tested to obtain a correct $p$ value. ${ }^{13}$

\section{Results}

Blood samples were collected from 327 patients but in only $248(76 \%)$ samples were there sufficient number of viable lymphocytes for full HLA typing. Results of 8 HLA-A antigens and 16 HLA-B antigens in the 248 patients are shown in the Table. No statistical differences were found between the patients with alcoholic liver disease and controls.

\section{Discussion}

This large study has therefore failed to confirm any evidence of an HLA associated genetic predisposition to alcoholic liver disease in Scotland and Newcastle. In particular, the frequencies of HLA-B8, $\mathrm{B} 13, \mathrm{~B} 15$, and B40 were little different between any of the patient groups or controls, thus confirming the other well documented negative report from Liverpool in the UK. ${ }^{6}$

Histocompatibility locus antigen associations with 
alcoholic liver disease that have been reported include an increased frequency of B5 ${ }^{14} \mathrm{~B} 8,{ }^{8}{ }^{15} \mathrm{~B} 13,{ }^{16}$, B15, ${ }^{7} \mathrm{~B} 40,{ }^{17} \mathrm{CW} 3,{ }^{18} \mathrm{DR} 2,{ }^{14}, \mathrm{DR} 3,{ }^{14}$, and DRW9 ${ }^{20}$ and reduced frequencies of $\mathrm{B} 13^{7}$ and $\mathrm{B} 40 . .^{\circ}$ Clearly, these results are confusing and contradictory. Most of the reports are small single studies with no confirmation from other sites. Failure to allow for the increased chance of obtaining a statistically significant result unless the number of antigens tested is taken into consideration accounts for several of these spurious reports. If the probability value obtained is multiplied by the number of antigens tested then only the following associations still hold true: B8, B13, B15, B40, CW3, DR2, and DRW9. HLA-B8 and CW3 are reported to be increased in alcoholic hepatitis whereas the remaining antigens are increased in alcoholic cirrhosis, B13 being reported as raised and reduced in prevalence.

Other factors which can produce misleading results are failure to select an adequate and representative control population, ${ }^{15}$ ethnic mismatching between populations, ${ }^{81+}$ lack of histological proof of the stage of liver disease in all cases ${ }^{x}$ and failure to examine differences between HLA antigens in all three histological stages of alcoholic liver disease..$^{1+1620}$

Overall, we would conclude that there is little evidence to support the concept that any subset of HLA-A and B loci grouped individuals have an increased susceptibility to alcohol induced liver damage. The relationship with DR antigen frequency should probably be further explored in the future.

This study was supported by the Scottish Home and Health Department. Grant K/MRS/50/C114.

\section{References}

1 Eghoje K N, Julh E. Factors determining liver damage in chronic alcoholics. Scand J Gastroenterol 1973; 8: 505-12.

2 Lelbach WK. Cirrhosis in the alcoholic and its relation to the volume of alcohol abuse. Ann N Y Acad Sci 1975; 252: $85-105$.

3 Galambos, JT. Alcoholic hepatitis. In: Schaffner F, Sherlock S, Leevy CM, eds. The liver and its diseases. New York: Intercontinental Medical Book Corporation, 1974: 255-67.

4 Sorensen TIA, Orholm M, Bentsen KD, Hoybye G, Eghoje K, Christoffersen P. Prospective evaluation of alcohol abuse and alcoholic liver injury in men as predictors of development of cirrhosis. Lancet 1984; ii: 241-4.

5 Eddleston ALWF, Davis M. Histocompatibility anti- gens in alcoholic liver disease. $\mathrm{Br}$ Med Bull 1982; 38: 13-6.

6 Faizallah R, Woodrow JC, Krasner NK, Walker RJ, Morris AI. Are HLA antigens important in the development of alcohol-induced liver disease? Br Med J 1982; 285: 533-4.

7 Doffeol M, Tongio MM, Gut J-P, et al. Relationship between 34 HLA-A, HLA-B and HLA-DR antigens and three serological markers of viral infections in alcoholic cirrhosis. Hepatology 1986; 6: 457-63.

8 Tamburro $\mathrm{CH}$, Fortwengler MP, Miller B, Mendenhall CL, Mendenhall VA. Cooperative Study Group on Alcoholic Hepatitis. Histocompatibility antigens (HLA) in alcoholic hepatitis. Hepatology 1986; 6: 777.

9 Hislop WS, Bouchier IAD, Allan JG, et al. Alcoholic liver disease in Scotland and Northeastern England: presenting features in 510 patients. $Q J$ Med 1983; 52: 232-43.

10 Boyum A. A one-stage procedure for isolation of granulocytes and lymphocytes from human blood. Scand J Clin Lab Invest 1968; 21: suppl 97: 51-76.

11 Kissmeyer-Nielsen F, Dick HM. Lymphocytotoxicity testing. In: Dick HM, Kissmeyer-Nielsen F, eds. Histocompatability techniques. Amsterdam: North Holland Elsevier, 1979: 9-37.

12 Collaborative report. HLA-A and B antigen frequencies in the U.K. A collaborative report from 11 centres. Tissue Antigens 1981; 18: 63-5.

13 Svejgaard A, Ryder LP. Disease associations. In: Dick HM, Kissmeyer-Nielsen F, eds. Histocompatibility techniques. Amsterdam: North Holland Elsevier, 1979: 185-205.

14 Tait BD, Mackay IR. HLA and alcoholic cirrhosis. Tissue Antigens 1982; 19: 6-10.

15 Morgan MY, Ross MGR, Ng CM, Adams DM, Thomas HC, Sherlock S. HLA-B8, immunoglobulins and antibody responses in alcohol-related liver disease. $J$ Clin Pathol 1980; 33: 488-92.

16 Melendez M, Vargas-Tank L, Fuentes C, et al. Distribution of HLA histocompatibility antigens, ABO blood groups and $\mathrm{Rh}$ antigens in alcoholic liver disease. Gut 1979; 20: 288-90.

17 Bell H, Nordhagen R, Orjasaeter H. Association between HLA-B40 and acute alcoholic hepatitis with cirrhosis and the lack of relation between carcinoembryonic antigen and HLA antigens in alcoholic liver disease. Scand J Gastroenterol 1983; 18: 267-71.

18 Shigetta $\mathrm{Y}$, Ishii $\mathrm{H}$, Takagi $\mathrm{S}$, et al. HLA antigens as immunogenetic markers of alcoholism and alcoholic liver injury. Pharmacol Biochem Behav 1980; 13: suppl 1: 89-94.

19 Bron B, Kubski D, Widmann JJ, von Fliedner V, Jeannet $M$. Increased frequency of DR3 antigen in alcoholic hepatitis and cirrhosis. Hepato-gastroenterol 1982; 29: 183-6.

20 Miyamoto $\mathrm{K}$, Ishii $\mathrm{H}$, Takata $\mathrm{H}$, et al. Association of HLA-B40 and DRW9 with Japanese alcoholic liver cirrhosis. Pharmacol Biochem Behav 1983; 18: suppl 1: 467-71. 